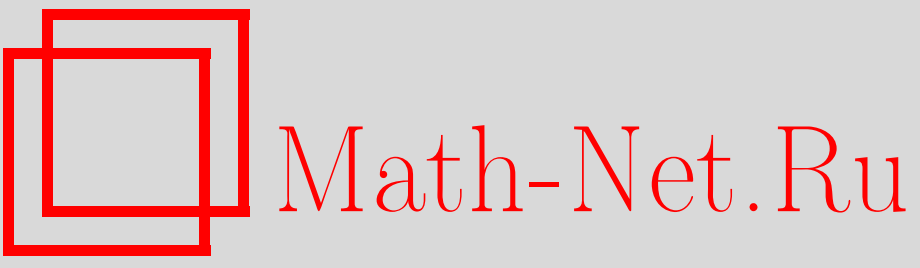

Четвертый Европейский математический конгресс, УМH, 2004, том 59, выпуск 1, 191

DOI: https://doi.org/10.4213/rm1665

Использование Общероссийского математического портала Math-Net.Ru подразумевает, что вы прочитали и согласны с пользовательским соглашением

http://www.mathnet.ru/rus/agreement

Параметры загрузки:

IP : 54.81 .137 .203

26 апреля 2023 г., 18:09:23 


\section{Четвертый Европейский математический конгресс}

С 27 июня по 2 июля 2004 года в Стокгольме будет проходить Четвертый Европейский математический конгресс, информационные сообшения о котором размешаются на сайте http://www.math.kth.se/4ecm/.

Председателем Научного комитета является Леннарт Карлесон, председателем Оранизационного комитета - Ари Лаптев.

Девис Конгресса: Математика в науке и технологии. Несколько Нобелевских лауретов откликнулись на приглашение выступить на Конгрессе о роли математики в развиваемых ими направлениях исследований.

В период проведения Конгресса планируется проведение спутниковых конференций.

На Конгрессе будут вручены десять премий лучшим молодым математикам. Председателем Комитета по наградам назначена Нина Уральцева (Санкт-Петербург). Будет представлена премия имени Феликса Кляйна, комитет по присуждению которой в настоящее время полностью сформирован. 